\title{
Effect of temporal lakes on avifaunal composition at the Southeast of Isthmus of Tehuantepec, Oaxaca, Mexico
}

\author{
Tamara Rioja-Paradela ${ }^{1,2}$, Arturo Carrillo-Reyes ${ }^{1,2 *}$ \& Eduardo Espinoza-Medinilla ${ }^{1}$ \\ 1. Sustentabilidad y Ecología Aplicada, Universidad de Ciencias y Artes de Chiapas. Libramiento Nte. Pte. 1150, Col. \\ Lajas Maciel, C.P. 27000, Tuxtla Gutiérrez, Chiapas, México; tamararioja@gmail.com, \\ arturocarrilloreyes@gmail.com, eduardo.espinoza@unicach.mx \\ 2. Oikos: Conservación y Desarrollo Sustentable, A.C., Calle Bugambilias 5, Col. Bismark, C.P. 29267, San Cristóbal \\ de las Casas, Chiapas, México. \\ * Correspondence
}

Received 14-I-2014. Corrected 25-VI-2014. Accepted 29-VII-2014.

\begin{abstract}
Oaxaca hosts one of the greatest biodiversity in México, occupying first place in avian diversity compared to other regions of the country. However, the area is undergoing serious problems such as high deforestation rates, soil erosion and over exploitation and extinction of species. These factors have all contributed to the current loss of biodiversity. Also, biological inventories are still incomplete. One of the least explored sites is the semiarid zone of Tehuantepec isthmus, around the locality of Santa Maria del Mar, Oaxaca, México. The area includes floodable grasslands, mangrove areas and dry forest, providing a range of potential habitats for different species. Our objective was to evaluate the effect of temporal lakes on spatial and temporal composition of the avifauna in Santa Maria del Mar, in order to generate information regarding this group within the region and the state, and to understand the importance of flood areas for resident and transitory birds. We conducted 12 avifauna surveys between July 2006 and June 2008, and established two transects of $2 \mathrm{~km}$ length in each of four habitat types (beach, grassland, dry forest, and mangrove). We found a total of 75 species, corresponding to 16 orders and 30 families. Within an area of $26 \mathrm{~km}^{2}$, we significantly found $10.1 \%$ of the total number of bird species recorded for the entire state, and $6.6 \%$ of the total reported in Mexico. The families most represented were: Ardeidae, Laridae and Scolopacidae. Over the entire study period, dry forest was the most diverse habitat; followed by mangrove, grassland and the beach. Of all the species recorded, $38.6 \%$ were found at the edge or in the temporal lakes. We found a significant difference in species composition between seasons in the grassland, but no difference in the other habitats. Our results showed a significant effect of temporary lakes on avian diversity during the wet season; it also demonstrated the importance of grassland conservation given its relevance for presence of waterbirds. We suggested a continued and more intense monitoring; and proposed the designation of the area as an Important Conservation Bird Area (AICA). Rev. Biol. Trop. 62 (4): 1523-1533. Epub 2014 December 01.
\end{abstract}

Key words: bird diversity, Important Conservation Bird Area, AICA, season effect, waterbirds, water bodies.

Mexico is considered one of the five megadiverse countries in the world; however, the country is undergoing a profound ecological crisis increased by global warming, high rates of deforestation, soil erosion and over exploitation and extinction of species. These factors have all contributed to the current loss of biodiversity (Toledo, 1992; Primack, Rozzi, Feinsinger, Dirzo, \& Massardo, 2001;
Martínez-Meyer, Sosa-Escalante, \& Noguera, 2014). In the interior of the country, the state of Oaxaca hosts one of the greatest biodiversity (García-Mendoza, Ordóñez-Díaz, \& BrionesSalas, 2004); it occupies the first place in terms of amphibians and birds diversity of (NavarroSigüenza et al., 2014; Parra-Olea, Flores-Villela, \& Mendoza-Almeralla, 2014), and third place for mastofauna (Sánchez-Cordero et al., 
2014). It is also one regions with the greatest number of endemic species (Flores-Villela \& Gerez, 1994), and one of the ten richest states in game species (Uribe \& Arita, 1998).

Several studies of faunal, particularly avian diversity, have been conducted in Oaxaca; however, the biological inventories are still incomplete, and large areas of the state remain unexplored (Binford, 1989; García-Mendoza et al., 2004; Grosselet \& Burcsu, 2005). As stated by Peterson, Escalona-Segura, Zyskowski, Kluza, \& Hernández-Baños (2003), and Navarro, García-Trejo, Peterson, \& RodríguezContreras (2004), the dry forest and semiarid zones require more detailed studies in order to fully reveal the faunal diversity in these little-explored areas of the state. Such knowledge would contribute to the establishment of appropriate strategies for the development of activities of conservation, research and/or use.

One of the least explored sites is found in the semiarid zone of Tehuantepec isthmus, on the peninsula located to the South of the Mar Tileme, around the locality of Santa María del Mar. The zone could have an enormous potential as a conservation area considering that the Isthmus of Tehuantepec is a center of vertebrate endemism, and has been classed as an IBA (Important Bird Area) by BirdLife International (BirdLife International, 2014). The study area is potentially important for both resident and transitory water birds given its location between the coastal lake and the Pacific Ocean. The zone comprises floodable grasslands, areas of mangrove and dry forest, thus providing a range of potential habitats for different species. The objective of this study was to evaluate the effect of temporal lakes on spatial and temporal composition of the avifauna in Santa María del Mar, in the Southeast of Tehuantepec isthmus in Oaxaca. We seek to generate information regarding this group within the region and the state, and to understand the importance of flood areas for resident and transitory birds.

\section{MATERIAL AND METHODS}

Study site: The study zone covers an area of $26 \mathrm{~km}^{2}$ around the locality of Santa María del

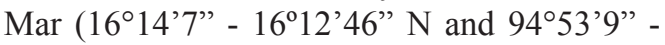
$\left.94^{\circ} 48^{\prime} 15^{\prime \prime} \mathrm{W}\right)$ in the municipality of Juchitán de Zaragoza, in Oaxaca state, Mexico. It is located between a coastal lake (Mar Tileme) and the Pacific Ocean. The town is inhabited by 862 people of indigenous (Huave) origin (Instituto Nacional de Estadística y Geografía, 2014). The main productive activities in the area are fishing, livestock production and, occasionally, seasonal agriculture and subsistence hunting (Carrillo-Reyes, Lorenzo, Naranjo, Pando, \& Rioja, 2010). The local climate type is Awo, tropical wet with a pronounced dry season, the driest month have a precipitation less than $60 \mathrm{~mm}$ and an average annual temperature of $25^{\circ} \mathrm{C}$ and average annual precipitation of $800 \mathrm{~mm}$; the wet season occurs between May and October with a short dry period in August, while the dry season begins in November and ends in April (García \& Comisión Nacional para el Conocimiento y Uso de la Biodiversidad [CONABIO], 1998).

Four habitat types are available for the avifauna in the area 1) beach, characterized as the limit between the continental zone and the ocean, with scarce plant cover and the presence of non-consolidated sand dunes; 2) extensive zones of grassland, with the dominant species Jouvea pilosa and isolated elements of species such as Opuntia tehuantepecana and $O$. decumbens; these areas are used for cattle husbandry; 3) dry forest areas, with species such as Cordia curassavica, Hippomane mancinella and Amphipterygium adstringens; and 4) small patches of mangroves, with species such as Conocarpus erecta and Rhizophora mangle (Vargas, 2000; Pérez-García, Meave, \& Gallardo, 2001; Rzedowski, 2006).

A total of twelve visits were made to the site between June 2006 and December 2008. 
Each visit lasted a minimum of eight consecutive days. Monitoring was made through variable-width line transects (Sutherland, 2006). Two observation transects of $2 \mathrm{~km}$ length were established in each of the four identified habitat types. A total of eight fixed transects were established across the entire study area and surveyed once during each visit. Each transect was surveyed simultaneously by two observers on foot twice a day: 06:00-10:00am and 15:0019:00pm. The point initiation of the transect was alternated for every survey in order to reduce the effect of time of the day on the recordings. Visual observations of the bird species were recorded during a total of 768 hours of observation in 98 days of field monitoring. Observations were carried out using a terrestrial telescope (Leica Televid APO-77® with a 20-60x ocular lens), as well as binoculars (Konus ${ }^{\circledR}, 10 \times 50$ ). Bird species were identified using the field guides of Peterson \& Chalif (1989), and Howell \& Webb (1995). Whenever possible, the birds were photographed in order to obtain an illustrative collection of the species recorded.

For each observed individual or group, the following parameters were recorded: transect, habitat type, coordinates, perpendicular distance to transect (using a Bushnell ${ }^{\circledR}$ Laser Legend 1200ARC rangefinder), species and number of individuals (Bibby, Burgess, Hill, \& Mustoe, 2000; Gregory, Gibbons, \& Donald, 2004). Location of the observed species on or at the edge of the temporal lakes (that were formed during the rainy season within the grassland habitat) was recorded. Temporal lakes were defined as bodies of water within the habitat that were unconnected to the ocean and formed from rainfall because of the relief of the terrain.

Scientific nomenclature, taxonomic arrangement and common names were described according to the American Ornithologists' Union [AOU] (2013). The total richness of the study area was determined considering all the species recorded. Abundance was calculated using the software Distance v.6, in which each line was used as a sampling unit, and by selecting the model that best fits the data. We used the Conventional Distance Sampling engine, and tried out various combinations of key functions to evaluate the fit of each model using the lowest value of the Akaike's Information Criterion (Thomas et al., 2010).

Well defined bird clusters were considered as one record. Birds recorded in flight were excluded, in order to avoid bias caused by species that present seasonal migration. A species was considered to be associated with the temporal lakes if it was recorded on or at the edge of any temporal wetland. In order to determine whether the sampling effort was representative of the avifaunal richness, a species accumulation curve was generated using the random species accumulation method (Gotelli \& Colwell, 2001) and the Chao index, using the Chao 2 variant, which estimate of species richness is based on incidence data (Vavrek, 2011).

Species were classified into the seasonal categories of resident breeder, summer resident, transient migrant, non-breeding visitor, and winter visitor according to Howell \& Webb (1995). In addition, species were categorized in terms of the foraging guild to which they belonged, classifying species as carnivores and carrion eaters, frugivores, insectivores, granivores, nectarivores, omnivores and piscivores (Graaf, Tilghman, \& Anderson, 1985; Navarro et al., 2004; The Cornell Lab of Ornithology, 2014).

Species included in any category of protection according to Mexican legislation (Secretaría de Medio Ambiente y Recursos Naturales [SEMARNAT], 2010), the IUCN (International Union for Conservation of Nature and Natural Resources [IUCN], 2013), and the appendices of CITES (Convention on International Trade in Endangered Species of Wild Fauna and Flora [CITES], 2013) were identified.

Alpha diversity was calculated using the diversity Simpson index for each habitat type in each season. Similarity between habitat types was calculated using quantitative Sorensen and qualitative Jaccard indices (Krebs, 1999; Moreno, 2001). Comparisons were made between the wet (May to October) and dry (November 
to April) seasons for each habitat type, using the same indicators. Furthermore, diversity was compared between seasons using the Sorensen and Jaccard coefficients, considering only those species recorded on or at the edge of the temporal lakes formed in this habitat. Also, a nonparametric Mann-Whitney U test was used to compare each habitat between the two seasons (Badii, Guillén, Araiza, Valenzuela, \& Landeros, 2012). The difference between seasons revealed by these indicators was considered to be due to the presence of the temporal lakes.
All analyses were conducted using the software $\mathrm{R}$ (R Core Team, 2014), with the packages " $\mathrm{R}$ Commander" (Fox, 2005), "vegan" (Oksanen et al., 2014) and "fossil" (Vavrek, 2011).

\section{RESULTS}

We found a total of 75 species over the course of the study (Table 1), representing 16 orders and 30 families. The most represented family was Ardeidae, with seven species, followed by Laridae and Scolopacidae. According

TABLE 1

List of bird species found in Santa María del Mar, Oaxaca. Species arrangement according to AOU (2013)

\begin{tabular}{|c|c|c|c|c|c|c|c|c|c|}
\hline Order/Family & Species & Common name & $\mathrm{M}^{1}$ & $\mathrm{Fg}^{2}$ & $\mathrm{Nom}^{3}$ & $\operatorname{Iucn}^{4}$ & $\mathrm{Bli}^{5}$ & Cites $^{6}$ & $\mathrm{Ab}^{7}$ \\
\hline \multicolumn{10}{|l|}{ Anseriformes } \\
\hline \multirow[t]{4}{*}{ Anatidae } & Dendrocygna autumnalis & Black-bellied Whistling-Duck & $\mathrm{R}$ & o & & $\mathrm{Lc}$ & & III & $0.0300 \pm 0.0009$ \\
\hline & Anas americana & American Wigeon & Wv & o & & $\mathrm{Lc}$ & & & $0.0255 \pm 0.0027$ \\
\hline & A. discors & Blue-winged Teal & Wv & 0 & & $\mathrm{Lc}$ & & & $0.0067 \pm 0.0055$ \\
\hline & Oxyura jamaicensis & Ruddy Duck & Wv & 0 & & $\mathrm{Lc}$ & & & $0.0074 \pm 0.0061$ \\
\hline \multicolumn{10}{|l|}{ Galliformes } \\
\hline \multicolumn{10}{|l|}{ Suliformes } \\
\hline $\begin{array}{l}\text { Phalacrocoracidae } \\
\text { Pelecaniformes }\end{array}$ & Phalacrocorax brasilianus & Neotropic Cormorant & $\mathrm{R}$ & $\mathrm{p}$ & & $\mathrm{Lc}$ & & & $0.0174 \pm 0.0239$ \\
\hline \multirow[t]{2}{*}{ Pelecanidae } & Pelecanus erythrorhynchos & American White Pelican & Wv & $\mathrm{p}$ & & $\mathrm{Lc}$ & & & $0.0592 \pm 0.0118$ \\
\hline & P. occidentalis & Brown Pelican & $\mathrm{Nb}$ & $\mathrm{p}$ & & $\mathrm{Lc}$ & & & $0.0340 \pm 0.0679$ \\
\hline \multirow[t]{7}{*}{ Ardeidae } & Tigrisoma mexicanum & Bare-throated Tiger-Heron & $\mathrm{R}$ & $\mathrm{p}, \mathrm{i}$ & $\operatorname{Pr}$ & $\mathrm{Lc}$ & & & $0.0029 \pm 0.0016$ \\
\hline & Ardea herodias & Great Blue Heron & Wv & $\mathrm{p}$ & & $\mathrm{Lc}$ & & & $0.0041 \pm 0.0028$ \\
\hline & A. alba & Great Egret & $\mathrm{R}$ & $\mathrm{p}$ & & $\mathrm{Lc}$ & & III & $0.0107 \pm 0.0123$ \\
\hline & Egretta thula & Snowy Egret & $\mathrm{R}$ & $\mathrm{p}$ & & $\mathrm{Lc}$ & & & $0.0177 \pm 0.0192$ \\
\hline & E. tricolor & Tricolored Heron & $\mathrm{R}$ & $\mathrm{p}, \mathrm{i}$ & & $\mathrm{Lc}$ & & & $0.0036 \pm 0.0020$ \\
\hline & E. rufescens & Reddish Egret & Wv & $\mathrm{p}, \mathrm{i}$ & $\operatorname{Pr}$ & $\mathrm{Nt}$ & & & $0.0026 \pm 0.0019$ \\
\hline & Bubulcus ibis & Cattle Egret & $\mathrm{R}$ & $\mathrm{i}$ & & $\mathrm{Lc}$ & & III & $0.0344 \pm 0.0216$ \\
\hline \multirow[t]{2}{*}{ Threskiornithidae } & Eudocimus albus & White Ibis & $\mathrm{R}$ & $\mathrm{p}, \mathrm{i}$ & & $\mathrm{Lc}$ & & & $0.0723 \pm 0.0052$ \\
\hline & Platalea ajaja & Roseate Spoonbill & $\mathrm{R}$ & $\mathrm{p}, \mathrm{i}$ & & $\mathrm{Lc}$ & & & $0.0310 \pm 0.0020$ \\
\hline \multicolumn{10}{|l|}{ Accipitriformes } \\
\hline \multirow[t]{2}{*}{ Cathartidae } & Coragyps atratus & Black Vulture & $\mathrm{R}$ & $\mathrm{c}$ & & $\mathrm{Lc}$ & & & $0.0333 \pm 0.0011$ \\
\hline & Cathartes aura & Turkey Vulture & $\mathrm{R}$ & $\mathrm{c}$ & & $\mathrm{Lc}$ & & & $0.0116 \pm 0.0001$ \\
\hline \multirow[t]{4}{*}{ Accipritidae } & Chondrohierax uncinatus & Hook-billed Kite & $\mathrm{R}$ & $\mathrm{c}$ & $\operatorname{Pr}$ & $\mathrm{Lc}$ & & III & $0.0027 \pm 0.0017$ \\
\hline & Buteogallus anthracinus & Common Black-Hawk & $\mathrm{R}$ & $\mathrm{c}$ & $\operatorname{Pr}$ & $\mathrm{Lc}$ & & & $0.0013 \pm 0.0000$ \\
\hline & Buteo magnirostris & Roadside Hawk & $\mathrm{R}$ & $\mathrm{c}$ & & $\mathrm{Lc}$ & & III & $0.0117 \pm 0.0001$ \\
\hline & B. jamaicensis & Red-tailed Hawk & Wv & $\mathrm{c}$ & & $\mathrm{Lc}$ & & & $0.0013 \pm 0.0000$ \\
\hline \multicolumn{10}{|l|}{ Gruiformes } \\
\hline Rallidae & Fulica americana & American Coot & Wv & $\mathrm{g}, \mathrm{i}$ & & $\mathrm{Lc}$ & & & $0.0262 \pm 0.0323$ \\
\hline \multicolumn{10}{|l|}{ Charadriiformes } \\
\hline Burhinidae & Burhinus bistriatus & Double-striped Thick-knee & $\mathrm{R}$ & 0 & & $\mathrm{Lc}$ & & III & $0.0132 \pm 0.0039$ \\
\hline \multirow[t]{2}{*}{ Recurvirostridae } & Himantopus mexicanus & Black-necked Stilt & $\mathrm{R}$ & $\mathrm{i}$ & & $\mathrm{Lc}$ & & & $0.0102 \pm 0.0160$ \\
\hline & Recurvirostra americana & American Avocet & Wv & $\mathrm{i}$ & & $\mathrm{Lc}$ & & & $0.0014 \pm 0.0018$ \\
\hline \multirow[t]{5}{*}{ Charadridae } & Pluvialis squatarola & Black-bellied Plover & Wv & $\mathrm{i}$ & & $\mathrm{Lc}$ & & & $0.0031 \pm 0.0020$ \\
\hline & Charadrius collaris & Collared Plover & $\mathrm{R}$ & $\mathrm{i}$ & & $\mathrm{Lc}$ & & & $0.0115 \pm 0.0144$ \\
\hline & C. nivosus & Snowy Plover & Wv & $\mathrm{i}$ & & $\mathrm{Lc}$ & & & $0.0054 \pm 0.0161$ \\
\hline & C. semipalmatus & Semipalmated Plover & $\mathrm{Wv}$ & $\mathrm{i}$ & & $\mathrm{Lc}$ & & & $0.0051 \pm 0.0046$ \\
\hline & C. vociferus & Killdeer & Wv & $\mathrm{i}$ & & $\mathrm{Lc}$ & & & $0.0081 \pm 0.0071$ \\
\hline Jacanidae & Jacana spinosa & Northern Jacana & $\mathrm{R}$ & $\mathrm{i}$ & & $\mathrm{Lc}$ & & & $0.0017 \pm 0.0026$ \\
\hline \multirow[t]{2}{*}{ Scolopacidae } & Numenius phaeopus & Whimbrel & Wv & $\mathrm{i}$ & & $\mathrm{Lc}$ & & & $0.0037 \pm 0.0061$ \\
\hline & N. americanus & Long-billed Curlew & Wv & $\mathrm{i}$ & & $\mathrm{Lc}$ & $\mathrm{Nt}$ & & $0.0037 \pm 0.0061$ \\
\hline
\end{tabular}


TABLE 1 (Continued)

\begin{tabular}{|c|c|c|c|c|c|c|c|c|c|}
\hline Order/Family & Species & Common name & $\mathrm{M}^{1}$ & $\mathrm{Fg}^{2}$ & $\mathrm{Nom}^{3}$ & $\mathrm{Iucn}^{4}$ & $\mathrm{Bli}^{5}$ & Cites $^{6}$ & $\mathrm{Ab}^{7}$ \\
\hline & Arenaria interpres & Ruddy Turnstone & Wv & $\mathrm{i}$ & & Lc & & & $0.0024 \pm 0.0046$ \\
\hline & Calidris himantopus & Stilt Sandpiper & $\mathrm{T}$ & $\mathrm{i}$ & & Lc & & & $0.0051 \pm 0.0041$ \\
\hline & C. pusilla & Semipalmated Sandpiper & Wv & $\mathrm{i}$ & & Lc & & & $0.0044 \pm 0.0036$ \\
\hline & Phalaropus tricolor & Wilson's Phalarope & $\mathrm{T}$ & $\mathrm{i}$ & & Lc & & & $0.0020 \pm 0.0035$ \\
\hline \multirow[t]{4}{*}{ Laridae } & Leucophaeus atricilla & Laughing Gull & Wv & 0 & & Lc & & & $0.0041 \pm 0.0081$ \\
\hline & L. pipixcan & Franklin's Gull & $\mathrm{T}$ & 0 & & $\mathrm{Lc}$ & & & $0.0341 \pm 0.1170$ \\
\hline & Chlidonias niger & Black Tern & Wv & 0 & & Lc & & & $0.0024 \pm 0.0058$ \\
\hline & Thalasseus elegans & Elegant Tern & $\mathrm{T}$ & 0 & $\operatorname{Pr}$ & $\mathrm{Nt}$ & $\mathrm{Nt}$ & & $0.0367 \pm 0.0126$ \\
\hline \multicolumn{10}{|l|}{ Columbiformes } \\
\hline \multirow[t]{5}{*}{ Columbidae } & Columba livia & Rock Pigeon & $\mathrm{R}$ & $\mathrm{g}$ & & Lc & & III & $0.0119 \pm 0.0161$ \\
\hline & Patagioenas speciosa & Scaled Pigeon & $\mathrm{R}$ & $\mathrm{g}$ & $\operatorname{Pr}$ & $\mathrm{Lc}$ & & & $0.0146 \pm 0.0177$ \\
\hline & Zenaida asiatica & White-winged Dove & Wv & $g, f$ & & Lc & & & $0.0187 \pm 0.0359$ \\
\hline & Columbina inca & Inca Dove & $\mathrm{R}$ & $\mathrm{g}$ & & Lc & & & $0.0102 \pm 0.0132$ \\
\hline & C. passerina & Common Ground-Dove & $\mathrm{R}$ & $\mathrm{g}$ & & Lc & & & $0.0146 \pm 0.0236$ \\
\hline \multicolumn{10}{|l|}{ Cuculiformes } \\
\hline \multirow[t]{2}{*}{ Cuculidae } & Coccyzus minor & Mangrove Cuckoo & $\mathrm{R}$ & o & & $\mathrm{Lc}$ & & & $0.0020 \pm 0.0052$ \\
\hline & Crotophaga sulcirostris & Groove-billed Ani & $\mathrm{R}$ & $\mathrm{i}, \mathrm{f}$ & & $\mathrm{Lc}$ & & & $0.0222 \pm 0.0080$ \\
\hline \multicolumn{10}{|l|}{ Caprimulgiformes } \\
\hline \multirow[t]{2}{*}{ Caprimulgidae } & Chordeiles acutipennis & Lesser Nighthawk & Wv & $\mathrm{i}$ & & $\mathrm{Lc}$ & & & $0.0020 \pm 0.0039$ \\
\hline & C. minor & Common Nighthawk & $\mathrm{T}$ & $\mathrm{i}$ & & $\mathrm{Lc}$ & & & $0.0027 \pm 0.0030$ \\
\hline \multicolumn{10}{|l|}{ Trogoniformes } \\
\hline \multicolumn{10}{|l|}{ Coraciiformes } \\
\hline \multicolumn{10}{|l|}{ Piciformes } \\
\hline $\begin{array}{l}\text { Picidae } \\
\text { Falconiformes }\end{array}$ & Melanerpes aurifrons & Golden-fronted Woodpecker & $\mathrm{R}$ & $\mathrm{i}$ & & $\mathrm{Lc}$ & & & $0.0058 \pm 0.0111$ \\
\hline \multirow[t]{2}{*}{ Falconidae } & Caracara cheriway & Crested Caracara & $\mathrm{R}$ & $\mathrm{c}$ & & Lc & & II & $0.0059 \pm 0.0028$ \\
\hline & Falco peregrinus & Peregrine Falcon & Wv & c & $\operatorname{Pr}$ & $\mathrm{Lc}$ & & I & $0.0002 \pm 0.0016$ \\
\hline \multicolumn{10}{|l|}{ Psittaciformes } \\
\hline \multicolumn{10}{|l|}{ Passeriformes } \\
\hline \multirow[t]{5}{*}{ Tyrannidae } & Myiarchus nuttingi & Nutting's Flycatcher & $\mathrm{R}$ & $\mathrm{i}$ & & Lc & & & $0.0173 \pm 0.0312$ \\
\hline & Pitangus sulphuratus & Great Kiskadee & $\mathrm{R}$ & 0 & & $\mathrm{Lc}$ & & & $0.0465 \pm 0.0477$ \\
\hline & Myiodynastes luteiventris & Sulphur-bellied Flycatcher & $\mathrm{Sr}$ & $\mathrm{i}$ & & $\mathrm{Lc}$ & & & $0.0081 \pm 0.0157$ \\
\hline & Tyrannus verticalis & Western Kingbird & Wv & $\mathrm{i}$ & & Lc & & & $0.0048 \pm 0.0073$ \\
\hline & T. forficatus & Scissor-tailed Flycatcher & Wv & $\mathrm{i}$ & & Lc & & & $0.0054 \pm 0.0089$ \\
\hline Corvidae & Calocitta formosa & White-throatedMagpie-Jay & $\mathrm{R}$ & 0 & & $\mathrm{Lc}$ & & & $0.0428 \pm 0.0298$ \\
\hline Alaudidae & Eremophila alpestris & Horned Lark & $\mathrm{R}$ & $\mathrm{g}, \mathrm{i}$ & & Lc & & & $0.0012 \pm 0.0022$ \\
\hline \multirow[t]{2}{*}{ Hirundinidae } & Progne chalybea & Gray-breasted Martin & $\mathrm{R}$ & $\mathrm{i}$ & & Lc & & & $0.0061 \pm 0.0210$ \\
\hline & Hirundo rustica & Barn Swallow & Wv & $\mathrm{i}$ & & Lc & & & $0.0041 \pm 0.0078$ \\
\hline Mimidae & Mimus gilvus & Tropical Mockingbird & $\mathrm{R}$ & 0 & & $\mathrm{Lc}$ & & & $0.0163 \pm 0.0256$ \\
\hline \multirow[t]{2}{*}{ Emberizidae } & Aimophila rufescens & Rusty Sparrow & $\mathrm{R}$ & $\mathrm{g}, \mathrm{i}$ & & $\mathrm{Lc}$ & & & $0.0441 \pm 0.0807$ \\
\hline & Passerculus sandwichensis & Savannah Sparrow & Wv & $\mathrm{g}, \mathrm{i}$ & & Lc & & & $0.0115 \pm 0.0201$ \\
\hline \multirow[t]{5}{*}{ Icteridae } & Agelaius phoeniceus & Red-winged Blackbird & $\mathrm{R}$ & 0 & & Lc & & & $0.0048 \pm 0.0073$ \\
\hline & Sturnella magna & Eastern Meadowlark & $\mathrm{R}$ & $\mathrm{i}$ & & $\mathrm{Lc}$ & & & $0.0068 \pm 0.0082$ \\
\hline & Quiscalus mexicanus & Great-tailed Grackle & $\mathrm{R}$ & 0 & & Lc & & & $0.0350 \pm 0.0329$ \\
\hline & Icterus pustulatus & Streak-backed Oriole & $\mathrm{R}$ & 0 & & $\mathrm{Lc}$ & & & $0.0095 \pm 0.0183$ \\
\hline & I. gularis & Altamira Oriole & $\mathrm{R}$ & 0 & & $\mathrm{Lc}$ & & & $0.0234 \pm 0.0373$ \\
\hline
\end{tabular}

1. Migratory status $(\mathrm{Sr}=\mathrm{Summer}$ resident, $\mathrm{R}=$ Resident breeder, $\mathrm{T}=$ Transient migrant, $\mathrm{Wr}=$ Winter visitor, and $\mathrm{Nb}=\mathrm{Non}$ breeding visitor).

2. Foraging guild ( $\mathrm{c}=$ carnivores and carrion eaters, $\mathrm{f}=$ frugivores, $\mathrm{g}=$ granivores, $\mathrm{i}=$ insectivores, $\mathrm{o}=$ omnivorous, $\mathrm{p}=$ piscivorous).

3. Mexican legislation category according to SEMARNAT (2010), Pr=Special protection.

4. Red list category (IUCN, 2013; Lc=Least concern, $\mathrm{Nt}=$ Near threatened).

5. BirdLife International category $(\mathrm{Nt}=\mathrm{Near}$ threatened and $\mathrm{Dd}=$ Data deficient $)$.

6. Appendices of CITES (2013).

7. Abundance (individuals/ha) and standard deviation $( \pm)$. 
to the Chao estimator, the maximum value for species in the area is 85 , which indicates that $88.2 \%$ of the species were recorded.

Among the four habitat types, the grassland presented the greatest species richness, with $74.6 \%(n=56)$ of the species observed in the entire area; it was followed by the dry forest with $52 \%(n=39)$, the mangrove with $49.3 \%$ $(n=37)$, and the beach with $28 \%(n=21)$ of the total species. However, the analysis of the richness between seasons revealed differences; during the wet season, the results were similar to those observed over the entire study, with $66.6 \%(\mathrm{n}=50)$ of the species found in grassland, $52 \%(n=39)$ in the dry forest, $49.3 \%(n=37)$ in mangrove, and $26.6 \%(n=20)$ of the species in the beach habitat. In the case of the dry season, the habitat types with greatest richness were dry forest and mangrove, with $49.3 \%(n=37)$ and $48 \%(n=36)$ of the species, respectively; in the beach habitat, $28 \%(\mathrm{n}=21)$ of the species were recorded, while the grassland contained $26.6 \%(\mathrm{n}=20)$.

Regarding species seasonality, 54.6\% $(\mathrm{n}=41)$ of the total number of species recorded were permanent residents, while $34.6 \%(n=26)$ were winter visitors, and $9.3 \%(\mathrm{n}=7)$ were transient migrant species. In terms of foraging guild, the most common was that of the insectivores $(33.3 \%$ of the total number of species, $\mathrm{n}=25$ ), followed by the omnivores $(24 \%, n=18)$. The least common were the piscivores $(8 \%, \mathrm{n}=6)$, along with carnivores and carrion eaters $(10.6 \%, \mathrm{n}=8)$, and granivores $(5.3 \%, \mathrm{n}=4)$.

Regarding protected status, $10.6 \%(n=8)$ of the recorded species are included within the NOM-059-SEMARNAT-2010 under the category of "special protection". According to the IUCN and to BirdLife International, only $2.6 \%(n=2)$ of the recorded species are included in the category Near Threatened (NT), while $18.6 \%(\mathrm{n}=14)$ of the recorded species are found cataloged within the appendices of CITES (Table 1).

According to the abundance analysis, the most abundant species over the course of the entire study were: Pitangus sulphuratus
(0.0465 \pm 0.0477 individuals/ha), Aimophila rufescens $(0.0441 \pm 0.0807 \mathrm{ind} / \mathrm{ha})$ and Calocitta formosa $(0.0455 \pm 0.0372 \mathrm{ind} / \mathrm{ha})$, while the least abundant species were Falco peregrinus $(0.0002 \pm 0.0035 \mathrm{ind} / \mathrm{ha})$ and Trogon citreolus $(0.0005 \pm 0.0074 \mathrm{ind} / \mathrm{ha}$, Table 1$)$. Analyzing each season separately, however, the most abundant species during the wet season were Eudocimus albus $(0.0625 \pm 0.0541$ ind/ha), Aimophila rufescens (0.0589 \pm 0.0813 ind/ha) and Pelecanus erythrorhynchos $(0.0575 \pm 0.0820 \mathrm{ind} / \mathrm{ha})$; while the most abundant species during the dry season were Larus pipixcan $(0.0599 \pm 0.0805 \mathrm{ind} / \mathrm{ha})$, Calocitta formosa $(0.0520 \pm 0.0325 \mathrm{ind} / \mathrm{ha})$ and Colinus virginianus $(0.0409 \pm 0.0340 \mathrm{ind} / \mathrm{ha})$.

Diversity analysis using the diversity Simpson index revealed that over the entire study period, the most diverse habitat was the dry forest (inv $\mathrm{D}=0.9508$ ), followed by mangrove (invD=0.9480), grassland (invD=0.9386) and beach (invD $=0.8576$ ). Analyzing each season separately, the mangrove (invD $=0.9480$ ) was the most diverse habitat in the wet season, followed by the dry forest (invD $=0.9422$ ), grassland (invD=0.9234) and beach (invD=0.8125). In the dry season, the most diverse habitat was the dry forest (invD $=0.9557$ ), followed by mangrove (invD $=0.9469)$, grassland (invD $=0.8888$ ) and beach (invD $=0.8418$ ).

Comparing habitats over the entire study period with the Jaccard $(J)$ and Sorenson $(c S)$ coefficients, the highest similarity was found between the grassland and mangrove $(J=0.6395, q S=0.7801)$, followed by grassland and dry forest $(J=0.5282, q S=0.6913)$. The beach was least similar to the other available habitats. Similarity analysis between habitats in the wet season produced results similar to the analysis over the entire study period, with the greatest similarity found between grassland and mangrove $(J=0.6893, q S=0.8161)$, followed by grassland and dry forest $(J=0.4075$, $q S=0.5791)$. Once again, the beach presented the greatest dissimilarity with the other available habitat types. During the dry season, the most similar habitats were the dry forest and the grassland $(J=0.5186, q S=0.6830)$, followed 
by dry forest and mangrove $(J=0.1940$, $q S=0.3250$ ), while the beach was again the least similar to the other available habitat types.

Of all the species recorded, 38.6\% $(n=29)$ were found to be associated with the temporal lakes formed in the grassland during the wet season. According to the two coefficients, the grassland habitat was found to be of low similarity between the two seasons $(J=0.3774$, $q S=0.5480)$; however, a greater difference $(J=0.0580, q S=0.0115)$ was found between the two seasons in grassland when we exclude species not associated with the temporal lakes from analysis.

Comparison of each habitat between the two seasons using a non-parametric MannWhitney $U$ test produced similar results. A significant seasonal difference was found in the grassland ( $\mathrm{W}=4$ 463.5, $\mathrm{p}=0.0001$ ), while significant seasonal differences were not presented in the other habitats (mangrove, $\mathrm{W}=3$ 250, $\mathrm{p}=0.8876$; beach $\mathrm{W}=3$ 208.5, $\mathrm{p}=0.7571$; dry forest $\mathrm{W}=3334, \mathrm{p}=0.9667$ ).

\section{DISCUSSION}

This was the first study on the spatial and temporal composition of avifauna to be conducted in this zone, and therefore makes a valuable contribution to the knowledge of bird diversity in the Tehuantepec isthmus. The study also represents a contribution to the knowledge regarding birds of the Southern Pacific coast of Mexico (Hernández-Vázquez, 2000). The total number of species found $(\mathrm{N}=75)$ represented $10.1 \%$ of the total avifauna reported for Oaxaca and $6.6 \%$ of the total reported for Mexico (Navarro-Sigüenza et al., 2014). The species richness we found may therefore be interpreted as significant given the relatively small area $\left(26 \mathrm{~km}^{2}\right)$ of the study zone, which represents less than $1 \%$ of the total area of Oaxaca $\left(93793 \mathrm{~km}^{2}\right)$. Intensification of the monitoring could reveal increased richness, considering that species in flight and nocturnal species were not included in our study.

Given the scarcity of published studies about the avifauna in the Tehuantepec isthmus, literature regarding this group in other regions of the state was reviewed. In this context, the number of species (113) reported by Vázquez, Moya, \& Arizmendi (2009) is similar, but within a notably larger area. Our results illustrated the requirement of conducting exhaustive inventories in the zone and in adjacent areas, including species in flight and nocturnal species, which would increase the number of records. There is also a clear necessity to implement local and regional strategies for conservation in the study area. We would suggest the inclusion of this zone within the "Áreas de Importancia para la Conservación de las Aves" (Important Area for Conservation of Birds, AICA) in México. The study zone could be included within Category one of this system, given that it corresponds to a "site that presents significant numbers of species cataloged as threatened, in danger of extinction, vulnerable or numerically diminished" (CONABIO, 2004).

It was clear that the community of birds present in the zone were heavily influenced, in terms of both specific composition and abundance, by the presence of avifauna from coastal or aquatic zones. The most abundant species were those associated with aquatic habitats (e.g., Ardeidae, Laridae). We consider this to be the direct result of the presence of temporal lakes during the wet season creating a suitable habitat for these species. The temporal lakes were found to cause a significant difference in the avifaunal diversity of the grassland between the two seasons studied. As stated by CupulMagaña (2000), the lakes represent an important habitat for coastal birds, providing a food source as well as sites for resting and reproduction. This condition elevated the diversity recorded in the grassland, making it one of the most diverse habitats across both the seasons, hosting not only grassland species but also those of the dry forest and the coastal zones.

We propose that the grassland and the temporal lakes represent a conservation priority since they sustain an important diversity of birds between the seasons. Importance of the lakes as feeding, resting and reproduction sites has been widely reported (Ntiamoa-Baidu, 
Nyame, \& Nuoh, 2000; Hattori \& Mae, 2001; Zárate-Ovando, Palacios, \& Reyes-Bonilla, 2008), therefore the modification or elimination of the flooding or lakes could reduce the presence of certain species, as described by Asamoah, Bork, \& Thompson (2011). Conversely, maintenance of the flooding, together with other habitat characteristics, could increase the viability of the existing bird populations, as demonstrated in the study of Hinojosa-Huerta, Iturribarria-Rojas, Zamora-Hernandez and Calvo-Fonseca (2008).

It is necessary to continue the monitoring conducted in this study. There are still areas close to the coastal lakes Superior and Inferior in which no studies of avifaunal diversity have been conducted. Furthermore, it is necessary to further the knowledge regarding species of nocturnal habit and rare species, and to assess conservation risk due to proposed establishment of thousands of wind turbines (McAndrews \& Montejo Díaz, 2010; Villegas, 2010). The effect of the wind farms on regional avifaunal diversity should be monitored and, where possible, necessary recommendations should be made to the relevant authorities and businesses responsible in order to minimize the effect of such structures on the movement and survival of the avifauna.

The only species that was considered rare in our study was the peregrine falcon (Falco peregrinus), since it was only recorded on two occasions. This was a valuable finding that provides an update on the current distribution of this species, which merits an in-depth study as suggested by Grosselet (2001).

Across the region, extraction of wildlife for food, pets or sale to third parties are common; these activities are related to deeply rooted traditions and to the conditions of marginalization and poverty that are prevalent in the zone (Vargas, 2000; Carrillo-Reyes et al., 2010). Bird species such as Dendrocygna autumnalis, Burhinus bistriatus, Mimus gilvus, Aratinga canicularis, Icterus pustulatus, among others, have been captured and used as pets and sometimes sold to buyers in other locations (Agencia Municipal de Santa María del Mar, Oaxaca, personal communication). In the face of high levels of marginalization and frequent ethnic conflicts (Carrillo-Reyes et al., 2010), it is necessary to establish mechanisms of conservation that allow the maintenance of alternative local incomes as well as ensuring the permanence of the avifaunal diversity. The establishment of Management Units for the Conservation of Wildlife (Unidades de Manejo para la Conservación de la Vida Silvestre, by their Spanish name), following the advice of research centers and universities, could represent a viable alternative.

These strategies, supported by more intensive monitoring, could include the maintenance of patches of vegetation typical of each of the habitats present, and even of the different phases of regeneration. This would foster occupation by different foraging guilds and habitat-specific species, as suggested by Bojorges-Baños \& López-Mata (2006). In this sense, Ausden, Sutherland, \& James (2001) suggest that the optimum conditions for certain wading bird species may be the presence of a mosaic of floodable and non-floodable grassland and shallow lakes. Furthermore, conservation of the grassland structure is vital to allow the continued formation of lakes during each wet season, since any modification of the soil surface use, for agriculture, livestock production or land leveling for infrastructural development, could alter the water storage capacity of the micro-basins, as well as the permeability of the soil (Fohrer, Haverkamp, Eckhardt, \& Frede, 2001).

\section{ACKNOWLEDGMENTS}

We are very grateful to the community and municipal authorities of Santa María del Mar, Oaxaca for their support during the course of this study. We thank Idea Wild for their kind donation of field equipment. We thank the anonymous reviewers for their valuable comments. 


\section{RESUMEN}

Efecto de las lagunas temporales sobre la composición de la avifauna al Sureste del Istmo de Tehuantepec, Oaxaca, México. Oaxaca alberga una biodiversidad de las más grandes en México, ocupando el primer lugar en diversidad de aves si se le compara con otras regiones del país. Sin embargo, el área sufre serios problemas tales como altas tasas de deforestación, erosión de suelo y sobre explotación y extinción de especies. Todos estos factores han contribuido con la actual pérdida de diversidad biológica. Además, los inventarios biológicos aún están incompletos. Una de las zonas menos exploradas es la parte semiárida del Istmo de Tehuantepec, en los alrededores de la localidad de Santa María del Mar, Oaxaca, México. El área incluye pastizales inundables, áreas de manglar y de selva seca, y provee de una gama de hábitat potenciales para diversas especies. Nuestro objetivo fue evaluar el efecto de las lagunas temporales en la composición espacial y temporal de la avifauna en Santa María del Mar, con el propósito de generar información relacionada con este grupo dentro de la región y del estado, además de comprender la importancia de las áreas inundables para las aves residentes y migratorias. Entre julio 2006 y junio 2008 realizamos 12 monitoreos de la avifauna, y establecimos dos transectos de $2 \mathrm{~km}$ de longitud para cada uno de los cuatro tipos de hábitat (playa, pastizal, selva seca y manglar). Encontramos un total de 75 especies, correspondendiendo a 16 órdenes y 30 familias. Dentro de un área de $26 \mathrm{~km}^{2}$, de manera significativa registramos el $10.1 \%$ del total de aves registradas para todo el estado y el $6.6 \%$ del total de especies registradas para México. Las familias mejor representadas fueron: Ardeidae, Laridae y Scolopacidae. Para todo el periodo de estudio, la selva seca fue el hábitat más diverso, seguido por el manglar, el pastizal abierto y la playa. Del total de especies registradas, el 38.6\% se encontraron en el borde o dentro de lagunas temporales. Encontramos una diferencia significativa en la composición de especies entre temporadas en el pastizal, pero no se encontró diferencia entre el resto de los hábitat. Nuestros resultados muestran un efecto significativo de las lagunas temporales sobre la diversidad de la avifauna durante la temporada lluviosa; también evidencian la importancia de la conservación de los pastizales, dada su relevancia para la presencia de aves acuáticas. Sugerimos realizar un monitoreo continuo e intensivo, y proponemos que la zona sea designada como un área de Importancia para la Conservación de las Aves (AICA).

Palabras clave: diversidad de aves, área de importancia para la conservación de las aves, Oaxaca, efecto estacional, aves acuáticas, cuerpos de agua.

\section{REFERENCES}

American Ornithologists' Union. (2013). The AOU Checklist of North American Birds, 7th Edition. AOU
Checklist of North and Middle American Birds. Retrieved from http://checklist.aou.org/

Asamoah, S. A., Bork, E. W., \& Thompson, J. E. (2011). Effects of Flood Seasonality and Frequency on Northern Pintails and other Breeding Ducks in Managed Prairie Wetlands. Western North American Naturalist, 71(3), 349-360.

Ausden, M., Sutherland, W. J., \& James, R. (2001). The effects of flooding lowland wet grassland on soil macroinvertebrate prey of breeding wading birds. Journal of Applied Ecology, 38(2), 320-338.

Badii, M. H., Guillén, A., Araiza, L. A., Valenzuela, J., \& Landeros, J. (2012). Métodos No-Paramétricos de Uso Común. International Journal of Good Conscience, 7(1), 132-155.

Bibby, C. J., Burgess, N. D., Hill, D. A., \& Mustoe, S. H. (2000). Bird Census Techniques (2nd ed.). London: Academic Press.

Binford, L. C. (1989). A Distributional Survey of the Birds of the Mexican State of Oaxaca. Ornithological Monographs, 43, 1-418.

BirdLife International. (2014). Endemic Bird Area factsheet: Isthmus of Tehuantepec. Retrieved from http:// www.birdlife.org/

Bojorges-Baños, J. C. \& López-Mata, L. (2006). Asociación de la riqueza y diversidad de especies de aves y estructura de la vegetación en una selva mediana subperennifolia en el centro de Veracruz, México. Revista Mexicana de Biodiversidad, 77(2), 235-249.

Carrillo-Reyes, A., Lorenzo, C., Naranjo, E. J., Pando, M., \& Rioja, T. (2010). Home range dynamics of the Tehuantepec Jackrabbit in Oaxaca, Mexico. Revista Mexicana de Biodiversidad, 81(1), 143-151. Retrieved from http://www.redalyc.org/resumen. oa? $\mathrm{id}=42515998019$

Comisión Nacional para el Conocimiento y Uso de la Biodiversidad. (2004, August 30). Áreas de Importancia para la Conservación de las Aves (AICAS). Retrieved from http://conabioweb.conabio.gob.mx/aicas/ doctos/aicas.html

Convention on International Trade in Endangered Species of Wild Fauna and Flora. (2013). The CITES Appendices. Retrieved from http://www.cites.org/eng/app/ index.php

Cupul-Magaña, F. G. (2000). Aves acuáticas del estero El Salado, Puerto Vallarta, Jalisco. Huitzil. Revista Mexicana de Ornitología, 1(1), 3-8.

Flores-Villela, O. \& Gerez, P. (1994). Biodiversidad y conservación en México: vertebrados, vegetación y uso del suelo (2nd ed.). México: Universidad Nacional Autónoma de México. Retrieved from http://www. biodiversidad.gob.mx/publicaciones/librosDig/pdf/ biodiversidadConservacion.pdf 
Fohrer, N., Haverkamp, S., Eckhardt, K., \& Frede, H. G. (2001). Hydrologic Response to land use changes on the catchment scale. Physics and Chemistry of the Earth, Part B: Hydrology, Oceans and Atmosphere, 26(7-8), 577-582.

Fox, J. (2005). The R Commander: A Basic Statistics Graphical User Interface to R. Journal of Statistical Software, 14, 1-42. Retrieved from http://www.jstatsoft. org/v14/i09/paper

García, E. \& Comisión Nacional para el Conocimiento y Uso de la Biodiversidad. (1998). Climas (Clasificación de Koppen, modificado por García). México, D.F.: Comisión Nacional para el Conocimiento y Uso de la Biodiversidad. Retrieved from http:// www.conabio.gob.mx/informacion/metadata/gis/ clima1mgw.xml? xsl=/db/metadata/xsl/fgdc html. $\mathrm{xs} 1 \&$ indent $=$ no

García-Mendoza, A. J., Ordóñez-Díaz, M. de J., \& BrionesSalas, M. (Eds.). (2004). Biodiversidad de Oaxaca. México: Universidad Nacional Autónoma de México.

Gotelli, N. J. \& Colwell, R. K. (2001). Quantifying biodiversity: procedures and pitfalls in the measurement and comparison of species richness. Ecology Letters, 4(4), 379-391.

Graaf, R. M. D., Tilghman, N. G., \& Anderson, S. H. (1985). Foraging guilds of North American birds. Environmental Management, 9(6), 493-536.

Gregory, R. D., Gibbons, D. W., \& Donald, P. F. (2004). Bird census and survey techniques. In W. J. Sutherland, I. Newton, \& R. E. Green (Eds.), Bird Ecology and Conservation; a Handbook of Techniques (1st ed., pp. 17-56). Oxford: Oxford University Press.

Grosselet, M. (2001). Presencia de Falco peregrinus en Oaxaca, México, a finales de la primavera. Huitzil. Revista Mexicana de Ornitología, 2(1), 1-2.

Grosselet, M. \& Burcsu, T. (2005). Notas sobre las Aves de Capulalpan de Méndez, Sierra Juárez, Oaxaca, México. Huitzil. Revista Mexicana de Ornitología, 6(2), 18-24.

Hattori, A. \& Mae, S. (2001). Habitat use and diversity of waterbirds in a coastal lagoon around Lake Biwa, Japan. Ecological Research, 16(3), 543-553.

Hernández-Vázquez, S. (2000). Aves acuáticas del estero La Manzanilla, Jalisco, México. Acta Zoológica Mexicana (nueva serie), 80, 143-153.

Hinojosa-Huerta, O., Iturribarria-Rojas, H., Zamora-Hernandez, E., \& Calvo-Fonseca, A. (2008). Densities, species richness and habitat relationships of the avian community in the Colorado River, Mexico. Studies in Avian Biology, 37, 74-82.

Howell, S. N. G. \& Webb, S. (1995). A Guide to the Birds of Mexico and Northern Central America. New York, NY: OUP Oxford.
Instituto Nacional de Estadística y Geografía. (2014). Censo de Población y Vivienda 2010. INEGI. Retrieved from http://www.censo2010.org.mx/

International Union for Conservation of Nature and Natural Resources. (2013). The IUCN Red List of Threatened. Species Version 2013.2. Retrieved from http:// www.iucnredlist.org/

Krebs, C. J. (1999). Ecological Methodology (2nd ed.). Menlo Park, CA: Benjamin Cummings.

Martínez-Meyer, E., Sosa-Escalante, J. E., \& Noguera, F. Á. (2014). El estudio de la biodiversidad en México: ¿una ruta con dirección? Revista Mexicana de Biodiversidad, 85(0), S1-S9. doi:10.7550/rmb.43248

McAndrews, A. E. \& Montejo Díaz, J. E. (2010). Birds from the Plains of Tehuantepec, Oaxaca, Mexico. The Southwestern Naturalist, 55(4), 569-575.

Moreno, C. E. (2001). Métodos para medir la biodiversidad. (Vol. 1). Zaragoza: CYTED, ORCYT/UNESCO and SEA. Retrieved from http://entomologia.rediris. es/sea/manytes/metodos.pdf

Navarro, S., García-Trejo, A. G., Peterson, A. T., \& Rodríguez-Contreras, V. (2004). Aves. In A. GarcíaMendoza, M. J. Ordoñez, \& M. Briones-Salas (Eds.), Biodiversidad en Oaxaca (pp. 391-421). México, D.F.: Universidad Nacional Autónoma de México.

Navarro-Sigüenza, A. G., Rebón-Gallardo, M. F., GordilloMartínez, A., Peterson, A. T., Berlanga-García, H., \& Sánchez-González, L. A. (2014). Biodiversidad de aves en México. Revista Mexicana de Biodiversidad, 85(0), S476-S495. doi:10.7550/rmb.41882

Ntiamoa-Baidu, Y., Nyame, S. K., \& Nuoh, A. A. (2000). Trends in the use of a small coastal lagoon by waterbirds: Muni Lagoon (Ghana). Biodiversity \& Conservation, 9(4), 527-539.

Oksanen, J., Blanchet, F. G., Kindt, R., Legendre, P., Minchin, P. R., O’Hara, R. B., \& Wagner, H. (2014). Vegan: Community Ecology Package (Version 2.141/r2836). Vienna, Austria. Retrieved from http://RForge.R-project.org/projects/vegan/

Parra-Olea, G., Flores-Villela, O., \& Mendoza-Almera1la, C. (2014). Biodiversidad de anfibios en México. Revista Mexicana de Biodiversidad, 85(0), S460-S466. doi:10.7550/rmb.32027

Pérez-García, E. A., Meave, J. A., \& Gallardo, C. (2001). Vegetación y flora de la región de Nizanda, istmo de Tehuantepec, Oaxaca, México. Acta Botánica Mexicana, 56, 19-88.

Peterson, A. T., Escalona-Segura, G., Zyskowski, K., Kluza, D. A., \& Hernández-Baños, B. E. (2003). Avifaunas of two dry forest sites in northern Oaxaca, Mexico. Huitzil. Revista Mexicana de Ornitología, 4(1), 3-9.

Peterson, T. \& Chalif, R. (1989). Aves de México: Guía de Campo. México: Diana. 
Primack, R., Rozzi, R., Feinsinger, P., Dirzo, R., \& Massardo, F. (2001). Fundamentos de conservación biológica. Perspectivas latinoamericanas. México: Fondo de Cultura Económica.

R Core Team. (2014). R: A Language and Environment for Statistical Computing (Version 3.1.0). Vienna, Austria: R Foundation for Statistical Computing. Retrieved from http://www.R-project.org/

Rzedowski, J. (2006). Vegetación de México. México: Comisión Nacional para el Conocimiento y Uso de la Biodiversidad. Retrieved from http://www. biodiversidad.gob.mx/publicaciones/librosDig/pdf/ VegetacionMx_Cont.pdf

Sánchez-Cordero, V., Botello, F., Martínez, J. J. F., GómezRodríguez, R. A., Guevara, L., Gutiérrez-Granados, G., \& Rodríguez-Moreno, Á. (2014). Biodiversidad de Chordata (Mammalia) en México. Revista Mexicana de Biodiversidad, 85(0), S496-S504. doi:10.7550/ rmb.31688

Secretaría de Medio Ambiente y Recursos Naturales. Norma Oficial Mexicana NOM-059-SEMARNAT-2010. Protección ambiental-Especies nativas de México de flora y fauna silvestres-Categorías de riesgo y especificaciones para su inclusión, exclusión o cambio-Lista de especies en riesgo, Pub. L. No. NOM-059-SEMARNAT-2010 § Diario Oficial de la Federación (2010). Retrieved from http:// dof.gob.mx/nota_detalle.php?codigo $=5173091 \& \mathrm{fec}$ ha $=30 / 12 / 2010$

Sutherland, W. J. (2006). Ecological census techniques a handbook. Cambridge, UK: Cambridge University Press.

The Cornell Lab of Ornithology. (2014). Neotropical Birds. Neotropical Birds. Retrieved from http://neotropical. birds.cornell.edu/portal/home

Thomas, L., Buckland, S. T., Rexstad, E. A., Laake, J. L., Strindberg, S., Hedley, S. L., \& Burnham, K. P.
(2010). Distance software: design and analysis of distance sampling surveys for estimating population size. Journal of Applied Ecology, 47(1), 5-14.

Toledo, V. M. (1992). Modernidad y Ecología. La Nueva Crisis Planetaria. In J. Martínez-Alier \& J. O’Connor (Eds.), Ecología política: cuadernos de debate internacional (1a ed., Vol. 12, pp. 9-22). Barcelona: FUHEM/ICARIA. Retrieved from http://www.ecologiapolitica.info/ep/3.pdf

Uribe, J. \& Arita, H. T. (1998). Distribución, diversidad y conservación de los mamíferos de importancia cinegetica en México. Acta Zoológica Mexicana (nueva serie), 75, 47-71.

Vargas, J. (2000). Distribución, abundancia y hábitat de la liebre endémica Lepus flavigularis (Mammalia: Lagomorpha). (Tesis de Maestría). Universidad Nacional Autónoma de México, México, D.F.

Vavrek, M. J. (2011). fossil: palaeoecological and palaeogeographical analysis tools. Palaeontologia Electronica, 14, 1T. Retrieved from http://palaeoelectronica.org/2011_1/238/index.html

Vázquez, L., Moya, H., \& Arizmendi, M. del C. (2009). Avifauna de la selva baja caducifolia en la cañada del río Sabino, Oaxaca, México. Revista Mexicana de Biodiversidad, 80(002), 535-549.

Villegas, R. (2010). Wildlife impact of wind power generation: Bird and bat collisions in Isthmus of Tehuantepec, Mexico. Presented at the 95th ESA Annual Meeting, Pittsburg. Retrieved from http://eco.confex. com/eco/2010/techprogram/P22129.HTM

Zárate-Ovando, B., Palacios, E., \& Reyes-Bonilla, H. (2008). Estructura de la comunidad y asociación de las aves acuáticas con la heterogeneidad espacial del complejo lagunar Bahía Magdalena-Almejas, Baja California Sur, México. Revista de Biología Tropical, 56(1), 371-389. 
